\title{
Meteorites as a scientific heritage
}

\section{Os meteoritos como património científico}

ANNARITA FRANZA ${ }^{1}$ GIOVANNI PRATESI ${ }^{2 *}$

1. Department of Earth Sciences, University of Firenze, Firenze, Italy

2. INAF-IAPS, Istituto di Astrofisica e Planetologia Spaziali, Roma, Italy

*giovanni.pratesi@unifi.it

\section{KEYWORDS}

This paper investigates the importance of meteorites as a scientific heritage. While the significance of meteorites as natural heritage is relatively easy to establish, the implication of their meaning as scientific heritage may be more difficult to define. With this aim in mind, in this paper, we present the catalogue standards for meteorite specimens, preserved either in natural history museums or in private collections, proposed by the Italian Istituto Centrale per il Catalogo e la Documentazione - ICCD (Central Institute for Catalogue and Documentation). This work outlines the structure of the catalogue card that describes the meteorite specimen along with other information related to the sample (e.g., archival documentation on collectors and traders, museum catalogues and inventories, general bibliography). This paper concludes discussing the cataloguing, according to ICCD standards, of two Renazzo meteorite specimens, which fell in the eponymous Italian village in 1824 and are now preserved at the Natural History Museum of the University of Firenze.

\section{Resumo}

O presente artigo investiga a importância dos meteoritos como património científico. Enquanto a relevância dos meteoritos como património natural é relativamente fácil de estabelecer, a implicação do seu significado como património científico poderá ser mais difícil de definir. Com esse objectivo em mente, no presente artigo apresentam-se as normas de catálogo para espécimes de meteoritos preservados, quer em museus de história natural, quer em coleções privadas, propostos pelo Istituto Centrale per il Catalogo e la Documentazione ICCD (Instituto Central para o Catálogo e Documentação). A estrutura do cartão de catálogo que descreve o espécime de meteorito, juntamente com outras informações relacionadas com a amostra (e.g. documentação de arquivo sobre colectores e comerciantes, catálogos de museus e inventários, bibliografia geral), é aqui delineada. Conclui-se com a discussão da catalogação de acordo com os padrões do ICCD, de dois espécimes de meteorito Renazzo, que caíram na aldeia italiana homónima em 1824 e que estão agora preservados no Museu de História Natural da Universidade de Florença.
Natural heritage

Scientific heritage

Cultural heritage

Meteorites

Preservation policies

Catalogue

\section{PALAVRAS-CHAVE}

Património natural Património científico Património cultural Meteoritos Políticas de preservação Catálogo 


\section{Introduction}

More than 50 tons of extraterrestrial material hit the Earth every year [1]. Meteorites are natural objects that have survived passage through the atmosphere and have reached the ground. An important difference exists between meteorite falls and meteorite finds: the former are meteorites collected after their fall was witnessed by observers or camera networks designed for monitoring fireballs; the latter are meteorites that were recovered by people but whose fall was not seen [3]. Each meteorite found is given a name by the Nomenclature Committee of the Meteoritical Society, usually that of the closest geographical landmark where it fell or was recovered. All known meteorites recognized by the Meteoritical Society are then included in the Meteoritical Bulletin Database (https:// www.lpi.usra.edu/meteor/metbull.php) a digital repository for basic information such as meteorite classification, place and year of discovery, whether it was observed to fall and references to catalogues (i.e., Catalogue of Meteorites from the Natural History Museum in London, MetBase, Antarctic Meteorite Newsletter) in which the meteorite is described.

Meteorites have been falling from the sky for aeons and have been investigated by scientists from a number of various disciplines. In 1858, Karl Ludwig Reichenbach (1788-1869) defined meteorites as cosmological, astronomical, physical, geological, chemical, mineralogical, and meteorological objects, highlighting the fact that they can be studied from different perspectives [4]. Even the term 'meteor' did not have the meaning it has got at the present. In his Lexicon Technicum, John Harris (1666-1719) described meteors as "various impressions made upon the Elements, exhibiting them in different forms (...) for the most part, they appear up in the Air, and they are either Fiery, Airy, or Watery" [5]. This description stemmed directly from Aristotle's Meteorologica (about 340 B.C.). The meteorological tradition, as stated by Jankovic (2006), remained entrenched in the Aristotelian view until the early nineteenth century when naturalists such as Ernst Chladni (1756-1827), Edward Howard (1774-1816) and Jean-Baptiste Biot (1774-1862) established the extraterrestrial origin of meteorites [6]. It is beyond the scope of this article to attempt a comprehensive reconstruction of the history of the meteoritics [9], nonetheless, even before scholars were convinced of the reality of meteorite falls from the outer space, meteorites were preserved in naturalistic museums and private collections throughout the world. In this regard, Burke [10] noted that the development of mineralogical collecting in the eighteenth century aided the recovery of meteorite specimens to the point that, after the midnineteenth century, meteorites collection became a symbol of a nation's scientific prestige and political power [11]. Burke [10] further pointed out how, between the late nineteenth and early twentieth century, the major European and American meteorite collections were established and opened to the public. From then on, the specimens in these collections have become an important source of extraterrestrial material for research purposes [14]. Hartmann's and Golia's [19] studies emphasize how meteorites have a social and cultural history, being surrounded by a significant corpus of myths, legends and folklore. In this regard, there have been numerous studies to investigate recorded accounts of meteoritic events in the oral traditions of Native Americans and Indigenous Australians [21]. For instance, the following studies were conducted using first-hand ethnographic records, literature, and field trip data to locate possible new impact structures or meteorites in Australia [23]. A number of authors have also recognized the use of meteorites in ancient human artefacts [27]. In short, as rightly remarked by Dorfman [33], the literature pertaining to meteorites in history strongly suggests that meteorites hold many levels of intangible heritage [34]. On this subject, a recent study by Wilson [35] concluded that the way in which planetary science is represented in natural history museums contributes to demonstrating the role of natural heritage as a means of moral and social witnessing. The author argued that in temporary or permanent exhibitions focusing on the formation of galaxies, stars and planets (e.g., the temporary exhibition 'The Evolving Universe' in The Arthur Ross Hall of Meteorites at the American Natural History Museum in New York, and the permanent exhibition 'Kosmos \& Sonnensystem' in the Museum für Naturkunde in Berlin), visitors observe, through the display of meteorites, not only the cosmic processes that have shaped the Solar System, but also how humans have interacted with this aspect of the environment thanks to the recovery and the analysis of meteorite fragments. Wilson [35] further points out that meteorite exhibitions demonstrated "how humanity is not the measure but a component in a wider system that is dependent upon the relationships that are built within it".

As stated before, meteorite collections are the subjects of studies looking into the evolution of both the universe and our planets [36]. Within these research projects, the analysis of historical documents, museum catalogues and inventories can lead both scientists and historians to the potential discovery of meteorite specimens previously unknown [41]. Meteorite collections in natural history museums are therefore representative of scientific as well as historical and cultural meanings that add extra value to a specimen. The issue that then naturally arises is how best to define museum meteorite collections in the heritage context. Revisiting the questions posed by De Chadervian [44], we can ask why meteorite collections in natural history museums are an issue we are invited to think about? Has the way in which meteorite specimens are valued and collected changed? Is the access to the samples an issue? Are science historians, museum curators and planetary scientists raising the issue?

These questions are especially true for the meteorites that have been recovered in Italy over the centuries. Due to physiographic factors, Italian meteorites are extremely 
rare and to date only 42 meteorites - both falls and finds have been officially approved by the Meteoritical Society. In spite of their small number and their belonging to a rather common typology (among these, 25 are ordinary chondrites) the study of Italian meteorites has long been the subject of intense historiographic and theoretical debates [45] such as the lively controversy that arose after the shower of stones that fell on Siena on 17 June 1794 [52]. Furthermore, Italian meteorites, such as those of other Western countries, are particularly sought out in the collector market due to their rarity. This can sometimes lead to false 'discoveries' designed to meet this market demand, e.g. the compelling case of the Castenaso meteorite in 2003 [54]. Some authors have also suggested that increased commerce in meteorites raises legal and ethical questions for museum curators, considering that international law about meteorite acquisition is nonuniform [55]. Natural history museums preserve the majority of the Italian meteorites known, as well as archival sources regarding the history of their discovery. These collections are repositories of specimens, documents and artefacts that allow reconstructing the processes by which they were assembled, beginning from the late seventeenth century, as the result of diverse cultural practices that involved different persons, places and things [57].

Starting from the methodological approach presented by Alberti [63], this work revisits the metaphor of "unpacking museum collections", proposed by Byrne et al. [64], in the light of the establishment of cataloguing standards for meteorite specimens. The creation of a standardized cataloguing card, elaborated by the Italian Central Institute for Catalogue and Documentation (Istituto Centrale per il Catalogo e la Documentazione - ICCD) together with museologists and academics, describes meteorite collections as a scientific heritage, problematising the specimens as both naturalistic and cultural objects through the compendium of data about their minerochemical classification, the roles they had over the times and in contemporary planetary science, the social relations they formed and the interactions they continue to have with varied persons and groups (i.e., collectors, scholars,

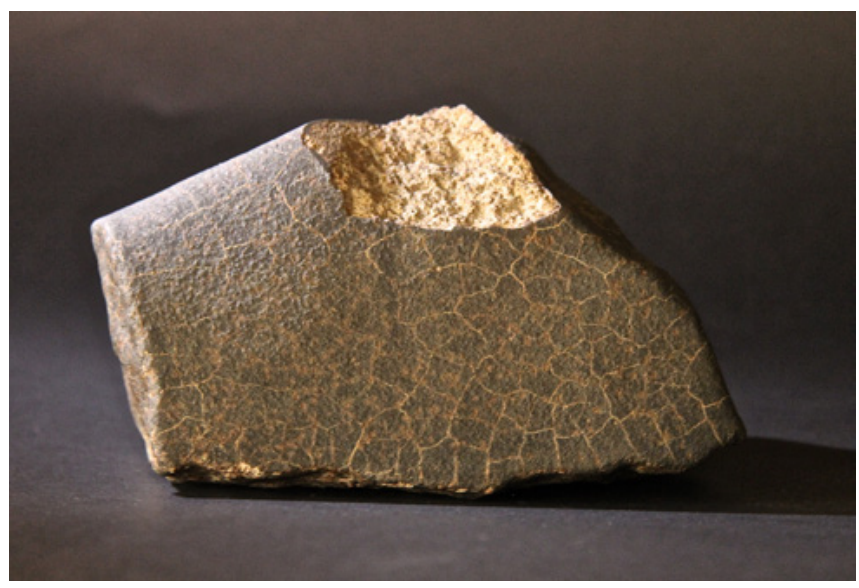

Figure 1. Ordinary chondrite meteorite with fusion crust (weight $2236 \mathrm{~g}$ ) Museum of Planetary Sciences - Prato, Italy, Inv. No. 1413/1. museum curators and visitors) within a complex network of agency. As Godsden et al. [65] and Bennett [66] have noticed, this agency does not end with the specimen acquisition, but it continues in the procedures of display as well as in the social and cultural practices or researching and learning which arise from the study of the single meteorite sample [67] (Figure 1).

The management of the catalogue cards through the SIGECweb digital database then shows how meteorite collections have not only a documentary value, but they represent a scientific heritage, the study of which helps to increase and improve our understanding of the cosmos, through the sharing of data otherwise unknown to the scientific community [68].

\section{The standardized cataloguing of meteorite collections}

Much has been said about the concept of heritage in museum studies [69]. Quoting the expression proposed by Boundia and Soubiran [71], the "heritage fever" - and thus the notion of heritage - has been the subject of countless studies since the 1980s. De Chadarevian [44] underlined how the term 'heritage' usually indicates "something preserved from the past" - from artefacts to buildings, from cities to landscapes - but also living cultures and intangible heritage (i.e., gestures, feasts, ceremonials) according to the definition proposed by the UNESCO [72]. Policies for safeguarding and management both material and intangible heritage have been developed by the International Council of Museums (ICOM), which established a new international committee dedicated to the cultural heritage of museum universities (UMAC) in 2002 [73]. In 2005, the Committee of Ministers of the Council of Europe adopted the Convention on the Value of Cultural Heritage for Society (also known as the

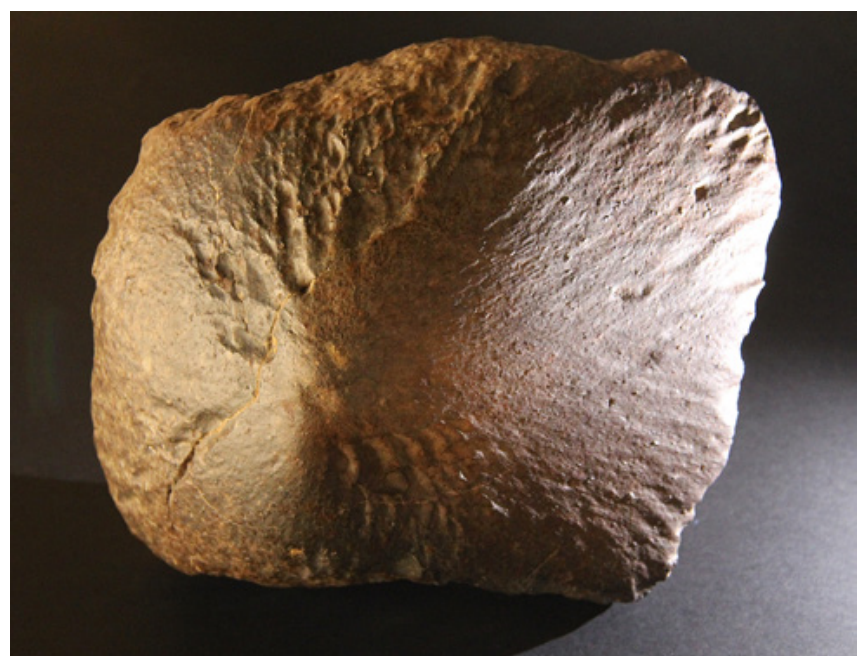

Figure 2. Acfer 371 oriented meteorite showing well visible regmaglypts (weight 9608 g). Museum of Planetary Sciences - Prato, Italy, Inv. No. 2282/1. 
Faro Convention), which emphasizes the concept of heritage and its relationships to communities and society [75].

Lourenço and Wilson [77] advocate the view that, while natural or industrial heritage are concepts of immediate understanding, the notion of scientific heritage is "diverse, complex, multi-layered, and more difficult to define." The authors then underline how the concept of scientific heritage lies "at the intersection of two distinct and complex worlds - the world of science and the world of (cultural) heritage." In this context, the term 'heritage' refers not only to buildings and landscapes of historical value (e.g., astronomical observatories and botanical gardens) but also - and among many others - to anatomical preparations, scientific instruments, herbaria, fossils, archives and documents, ethical issues in conducting research and teaching practices, meteorite specimens. This material is often dispersed in scientific museums or institutions and university collections [78].

Scientific heritage, due to the variety of the material and immaterial media that it encompasses, raises broadspectrum issues related to its preservation, conservation and dissemination. The problems related to the preservation of meteorite collections concern, for instance, the transfer of the specimens into research and teaching laboratories making the samples more exposed to the risk of damage or loss. This is especially true when samples are involved in inter-institutional loans under international research agreements. In this section, we, therefore, discuss how the standardized cataloguing of meteorites preserved in natural history museums - whether historical or newly acquired specimens - can prove to be a useful tool to safeguard their roles and identities as well as to promote their scientific heritage preservation and use (Figure 2). The case study research has been conducted on the legislation and regulations promoted in Italy regarding the standardized cataloguing of the planetological heritage (beni planetologici).

The decree 22 January 2004, n. 42 (Codice per i Beni Culturali e del Paesaggio, Code for Cultural Heritage and Landscape) acknowledged as cultural heritage all the collections preserved in public museums and institutions in Italy regardless the typology of the objects that are part of it (art. 10, part 2, letter a). In Attachment A (n. 13), the Code directly mentions as cultural heritage "collections and/or specimens belonging to zoological, botanical, mineralogical and anatomical collections". In 2007, the Ministry of Cultural Heritage and Activities (Ministero per $i$ Beni e le Culturali e per il Turismo MiBACT) in collaboration with the Conference of the Rectors of the Italian Universities (Conferenza dei Rettori delle Università Italiane-CRUI), ENEA (Agenzia nazionale per le nuove tecnologie, l'energia e lo sviluppo economico sostenibile), ICCD, the National Association of Scientific Museums (Associazione Nazionale Musei ScientificiANMS) scholars and museum practitioners, established a standardized procedure to catalogue objects identified as natural heritage. The ICCD realised six different catalogue cards for: botanical specimens (Beni Naturalistici,
Botanica-BNB), paleontological specimens (Beni Naturalistici, Paleontologia - BNP), zoological specimens (Beni Naturalistici, Zoologia - BNZ), mineralogical specimens (Beni Naturalistici, Mineralogia-BNM), petrological specimens (Beni Naturalistici, Petrologia - BNPE), planetological specimens (Beni Naturalistici, Planetologia - BNPL). The last type of catalogue card has been defined for the study of meteorite samples.

Tucci [85] noted that all the catalogue cards, generally speaking, contain: (a) both descriptive and more detailed data, which highlights the cultural value of the catalogued specimen; (b) geographical information (i.e., the place of recovery, the place where the specimen is actually preserved and/or previous institutions where it was stored); (c) information about other data possibly related to the specimens (i.e., archival documents, museum catalogues and inventories); (d) administrative data such as economic evaluations. The structure of the data is then organized in a series of sections, which are dedicated to a specific topic (e.g., identification of the specimen, location, scientific and historical background, technical data, archival or general documentation). Each catalogue card presents a set of guidelines for the standardized filling of the sections (i.e., which sections must be completed, which can be repeated for additional information, which need the use of a predefined vocabulary) as well as for management of the catalogue card on the digital database (SIGECweb). About filling some sections according to a predefined terminology, the ICCD guidelines provide for the use of an 'open' vocabulary or a 'closed' vocabulary. Open vocabularies consist of lists of terms that can be increased during the editing of a catalogue card, with the insertion of new headwords by the cataloguer. The proposals for updating the vocabularies are subsequently submitted to a scientific verification committee and, in case of acceptance, they are officially published on the ICCD website. Closed vocabularies consist of a series of predefined terms that cannot be updated by the cataloguer. Open and closed vocabularies may be formed by a list of terms, definitions, references to primary sources or general bibliography, thesauri. The cataloguing activity can be conducted at a (1) inventory level (i.e. the level of minimum information required for the correct preservation of the specimen as well as for the planning of conservation and valorisation activities); (2) pre-catalogue level that provides additional information deduced from the direct observation of the specimen; (3) catalogue level, which corresponds to a more in-depth study of the specimen (e.g., bibliographical and archival research). It is noteworthy to mention that the cataloguing system here described can be arranged from (1) to (3) depending on the type of sample to be catalogued. However, the main objective of any cataloguing level remains the precise identification of the specimen and its historical, cultural and geographical background, in order to emphasize the network of relations between the natural heritage and the territory [86]. 


\section{How to catalogue a meteorite? The cataloguing card BN-PL}

The catalogue card BN-PL consists of more than $400 \mathrm{sec}-$ tions. It is therefore not possible to describe all the individual sections, so this study discusses the most significant paragraphs of the card for the correct preservation, conservation and valorisation of a meteorite specimen [90].

After having established which institution is carrying out the cataloguing activities, the Object Section (OS) contains the essential information for the identification of the catalogued specimen. The name of the collection to which the specimen belongs must then be indicated in full. The Meteorite Systematics Section (MSS) provides for information about the classification of the specimen based on its mineralogical and petrographic characteristics as well as on its whole-rock chemical and O-isotopic compositions [3] (Figure 3). As Weisberg et al. [92] rightly pointed out meteorite classification is the basic framework from which planetary scientists and cosmochemists work and communicate. The process of classification evolves with both the collection of new data and the discovery of unknown meteorite types.
Therefore, it is also very important to reanalyse the historical meteorites in order to confirm their extra-terrestrial origin and to revise their classification. This is the reason why the catalogue card must provide accurate information about the meteorite analytical data.

The MSS section then contains information if the specimen was a fall or a find. This is an important distinction because finds are more prone to contamination with the terrestrial environment, depending on the time they spent on the ground [3, 92]. Most of the meteorites actually preserved in Italian natural history museums are falls. Nonetheless, in the last two decades, diverse institutions have increased their meteorite collections with finds recovered in hot and cold deserts [60, 93]. It is important to note that the date of the meteorite fall could not be the same as of the meteorite recovery. For instance, fragments of the Sikhote-Alin meteorite (Figure 4), which fell on the eponymous Russian mountains on 12 February 1947, are still being found today. The MSS then contains information about where the holotype is preserved and who holds the biggest meteorite specimen (i.e., naturalistic museum or private collector). Within this section, the cataloguer can

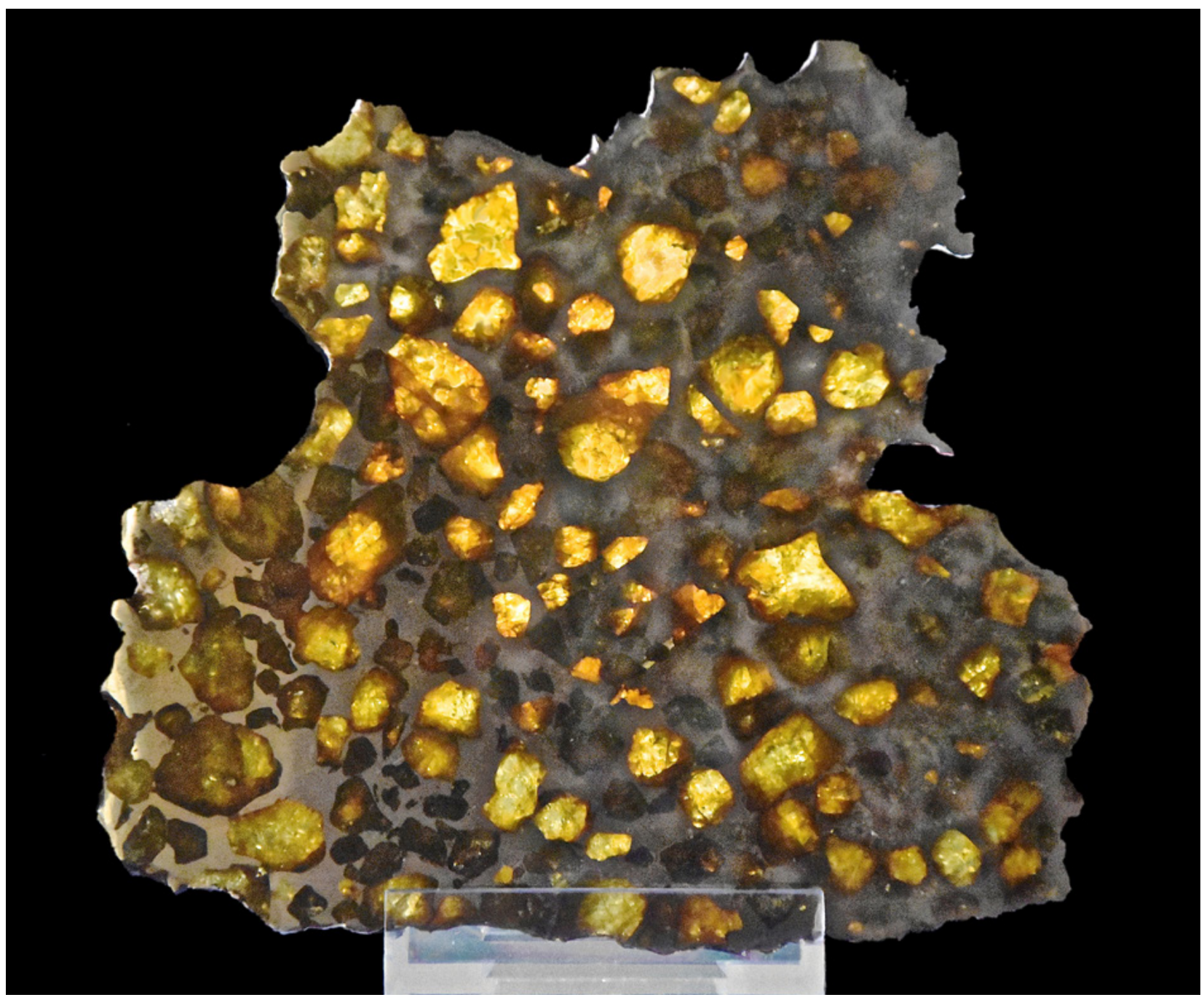

Figure 3. Slice of Imilac pallasite with olivine crystals embedded in metal (weight 199 g). Museum of Planetary Sciences - Prato, Italy, Inv. No. 1394/1. 


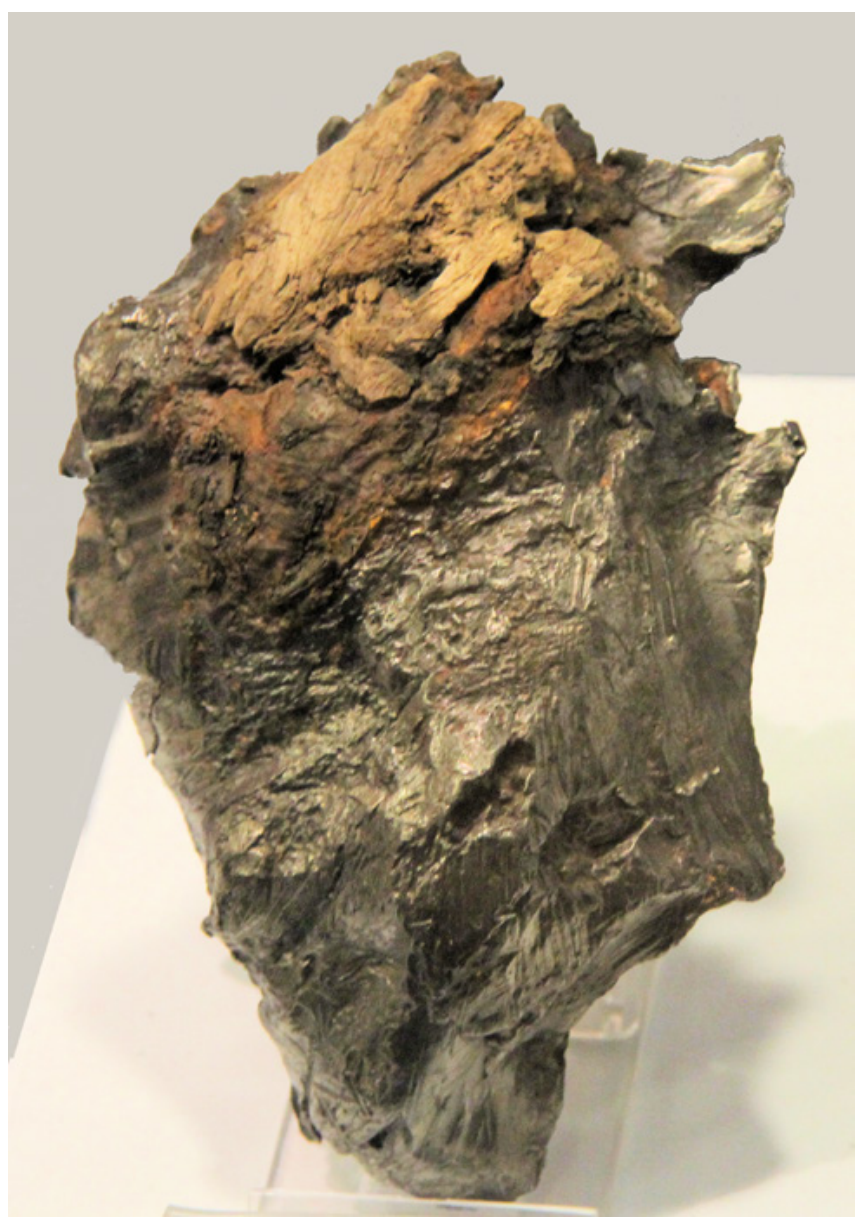

Figure 4. Sikhote Alin meteorite (weight $290 \mathrm{~g}$ ). On the upper side of the specimen, it can be noted a fragment of wood that remained attached on the hot meteorite surface following the impact with a tree. Museum of Planetary Sciences - Prato, Italy, Inv. No. 2241/1.

also enter data about the presence of meteorite fragments, thin sections and powder available for loan as well as general bibliography and any information taken from museum catalogues, inventories or original exhibition labels.

The subsequent section is dedicated to Meteorite Collection Data (MCD). In these paragraphs shall be included data about the year and the place where the meteorite specimen was found and any information concerning the scientific expedition that led to its discovery. As stated before, meteorites are given names based on the location in which they were recovered. Fragments from cold or hot desert areas are given names and numbers. For instance, Istifane 005 is a meteorite find that was collected in the Moroccan ridge of Istifane in 2017, and it is now preserved at the Florentine Natural History Museum. The cataloguer can specify all this information in MCD as well as other data about the mineralogical and petrographic characteristics of the collected meteorite. A specific subsection is then devoted to the description (about 2000 characters) of the paper labels attributed to the specimen during the meteorite-hunting expedition.

After providing detailed information on the scientific institution or the natural history museum preserving the specimen, the BN-PL catalogue card provides an economic evaluation of the meteorite fragment along with information about the collector and the collection in which the specimen is included. The economic evaluation of the single meteorite sample is a very important data that the cataloguing process returns to the community and stakeholders. In recent years there has been a growing interest in the processes for determining the economic value of naturalistic collections. This is an indicator useful for establishing the costs of protection, conservation, valorisation and insurance cover against theft, fire, and damage to be used even in the case of loans for temporary exhibitions or study purposes [91, 94]. As pointed out by Burke [10], museum curators complained from the 1840 s about the prices of meteorites in what seemed to be a chaotic market. An element that seemed to influence this chaotic market was, as Burke [10] further asserted, the total weight of the recovered specimen. In this regard, Buchner [102] made the first attempt to standardize meteorite pricing, listing 263 specimens held in various private and public collections and their total weight. A few decades later, Wülfing [103] brought Buchner's survey up to date, considering eight factors as determining meteorite exchange values: (1) the amount of preserved material, (2) the total weight of the petrographic group in which the meteorite was classified, (3) the number of owners, (4) the addition of a new fall or find to a group of limited weight, (5) the cost of acquisition, (6) the state of preservation, (7) the historical interest, and (8) whether the meteorite was a fall or a find. The factors 1-3 were then used in a mathematical formula to determine the correct exchange value of a meteorite specimen.

All the criteria listed in Wülfing's essay are still valid today and considered within the BN-PL catalogue card. Furthermore, as rightly pointed out by Moggi Cecchi et al. [104] the classification of newfound meteorites according to their mineralogical and petrographic characteristics (Figure 5), carried out by natural history museums on behalf of third parties, is a useful instrument in terms

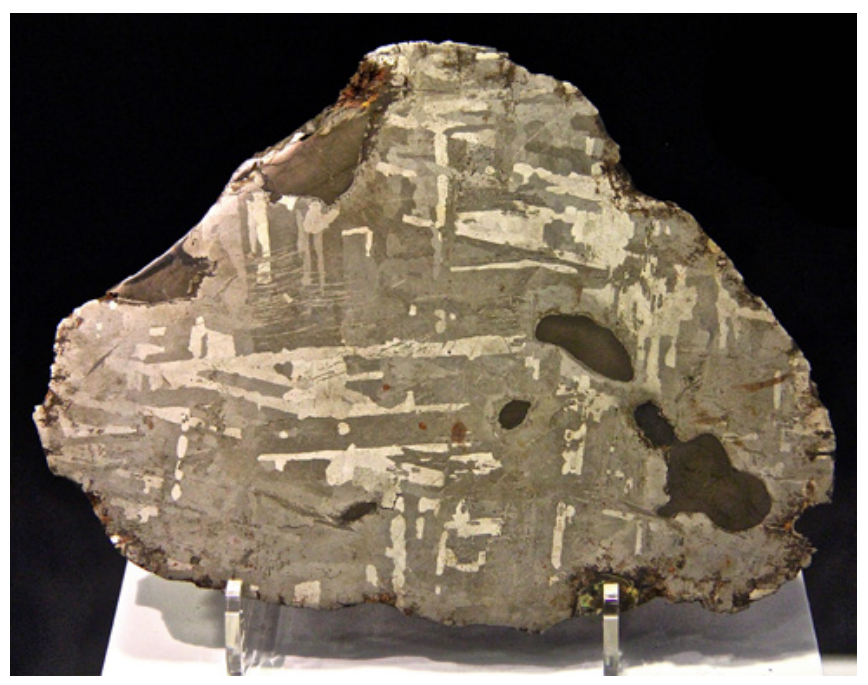

Figure 5. Slice of Nantan iron meteorite showing Widmanstätten figures (weight 3100 g). Museum of Planetary Sciences - Prato, Italy, Inv. No. 1364/2. 
of both economic enhancement of naturalistic heritage and improvement of museum's image in the scientific community. The next paragraph of the BN-PL catalogue card reports the coordinates $\mathrm{X}, \mathrm{Y}$ where the meteorite fragment was recovered. These parameters are very important because failure to report precise locality information makes it difficult for scientists to pair up recent finds with previous ones [105]. The last paragraphs describe technical and analytical data relative to the meteorite specimens including size, colour, shape, surface, interior features (Figure 6), weight, and magnetic properties. Information about meteorite care, preservation, previous restoration works, and laboratory analysis is also given within these sections.

The BN-PL catalogue card ends with bibliographical data on essays and scientific articles about the specimen as well as references to archival material. In this section, the cataloguer can also upload a high-resolution image relative to the sample along with the photo credits.

\section{The Renazzo meteorite (1824): cataloguing a meteorite specimen through the BN-PL card}

According to the chronicle written by Francesco Lenzi (dates uncertain) and now preserved at the Historical Archive of Cento [106], on 15 January 1824, a stone fell on the small village of Renazzo, in the current province of Ferrara (Italy). Three fragments of the meteorite were found, one of which was $5 \mathrm{~kg}$, for a total mass of $10 \mathrm{~kg}$. Two weeks later, Camillo Ranzani (1775-1841), the director of the Natural History Museum of Bologna from 1803 to 1841 [107], went to Renazzo to recover as many samples as possible. In 1827, he sent one of these specimens to the French chemist André Laugier (1770-1832) for analysis. The mineralogical and petrographic description of the fragments was then provided by Pierre Louise Antoine Cordier (1777-1861), who was a naturalist and a founder of the French Geological Society [108]. Cordier noted that the sample was not similar to other known meteorites, except for the black and glassy crust which partly covered its surface. On this basis, he classified the specimen as a meteorite vitreuse (vitreous meteorite) [109]. Contemporary petrological, geochemical and oxygen isotopic studies have identified the Renazzo meteorite as the holotype of the CR (Renazzo-type) carbonaceous chondrite group because of a set of properties that distinguishes it from other chondrite groups [110]. For this reason, the meteorite Renazzo is still today one of the most studied meteorites by the scientific community as well as one of the most sought-after on the collectors' market.

The Natural History Museum of the University of Firenze preserves two specimens of the Renazzo meteorite that have been catalogued through the BN-PL card. The first is a

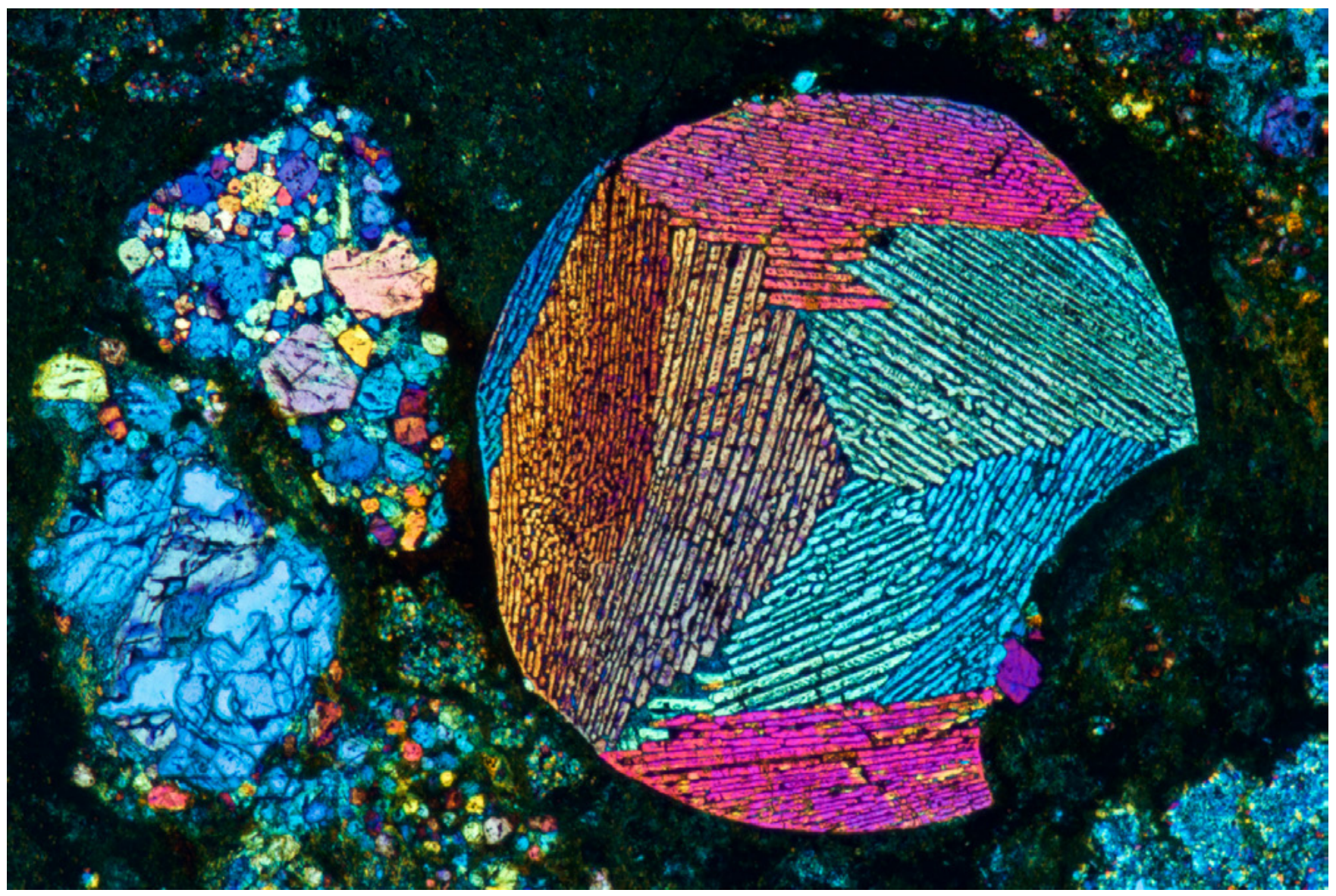

Figure 6. Cross polarized nicols image of a chondrite meteorite. It is to be noted the barred olivine chondrule on the right-middle of the image. Museum of Planetary Sciences - Prato, Italy. Photo credit Prof. Bernardo Cesare (University of Padova). 
Table 1. Extract of the BN-PL catalogue card for the Renazzo meteorite specimen (ICCD Cat. No. 01142167) preserved at the Natural History Museum (Collection of Mineralogy and Lithology) of the University of Firenze.

\begin{tabular}{|c|c|}
\hline ICCD catalogue number & 01142167 \\
\hline Name & Renazzo \\
\hline Genre & Chondrite \\
\hline Class & Carbonaceous Chondrite \\
\hline Group & CR \\
\hline Fall/Find & Fall \\
\hline Date & 1824 \\
\hline Locality & Renazzo, Province of Ferrara, Italy \\
\hline Type of localization & Recovery location - historical data \\
\hline Valuation & $2.500 €$ \\
\hline Weight & $70 \mathrm{~g}$ \\
\hline State of conservation & Good \\
\hline Laboratory analysis & Minerochemical analysis \\
\hline Type of acquisition & Donation \\
\hline Name of the donor & Camillo Ranzani \\
\hline Date of the donation & 1824 \\
\hline \multirow[t]{4}{*}{ Sources and documents } & Archivio Storico, Collezione di Mineralogia e Litologia, Appendice di Aumenti al Catalogo della Mineralogia del 1824, n. 00525. \\
\hline & Archivio Storico, Collezione di Mineralogia e Litologia, Catalogo della Mineralogia e Orittologia 1843-1845, n. 7148. \\
\hline & Archivio Storico, Collezione di Mineralogia e Litologia, Catalogo della Collezione di Meteoriti, 1947, n. 13770. \\
\hline & Archivio Storico, Museo Galileo, ARMU Affari 038, Carteggio della Direzione, gennaio-dicembre 1824, c. 37. \\
\hline
\end{tabular}

specimen of $70 \mathrm{~g}$ acquired by the Museum in 1824 (Figure 7, Table 1).

Table I illustrates data regarding the cataloguing of the Renazzo meteorite specimen using the BN-PL catalogue standard. The information shows the date of the fall, where the meteorite was recovered, and its minerochemical classification. Furthermore, the table indicates the state of conservation of the specimen, its economic valuation, and how it was acquired by the Florentine Natural History Museum. In this regard, it is interesting to note the information that stands out from the Sources and Documents (SD) field. This field is repeatable within the BN-PL card and contains all the references relative to the catalogued specimen. In this case, the SD reports the historical documentation about the Renazzo meteorite preserved both at the Historical Archive of the Natural History Museum (HA-NHM) of the University of Firenze and at the Historical Archive of the Galileo Museum (HAGM). The archival documents kept in HA-NHM reconstructs the trajectories of the Renazzo meteorite specimen within the Natural History Museum through catalogues and museum inventories. Thanks to the study of this material, it is possible to trace the "career" of the specimen from its acquisition in 1824 to 1947, and to analyse the different scientific contexts and the changes of value incurred by these shifts [111]. In this regard, the specimen was described in the Catalogue of the Mineralogical Collection (1843-1845) as a "meteoritic iron fallen on 15 January 1824 [112]". It will be necessary to wait until 1947, when the meteorite collection was first inventoried, to see the sample described as a meteorite whose economic value was 130 lire [113].
As stated by Alberti [63], collectors, curators, and scientists encountered museum objects in very different ways. For instance, things collected in the field, as meteorite specimens, can be connected to institutions and scientific practices, providing insights into the role of museums in scientific and civic culture. Of this, the HA-GM preserves the Archivio del Reale Museo di Fisica e Storia Naturale di Firenze (Archive of the Royal Museum of Physics and Natural History of Florence), a fund of more than 5700 documents covering a period of almost a century (17801872), and representing one of the most important sources to reconstruct the history of the Florentine Natural History Museum and its relationships with the main European

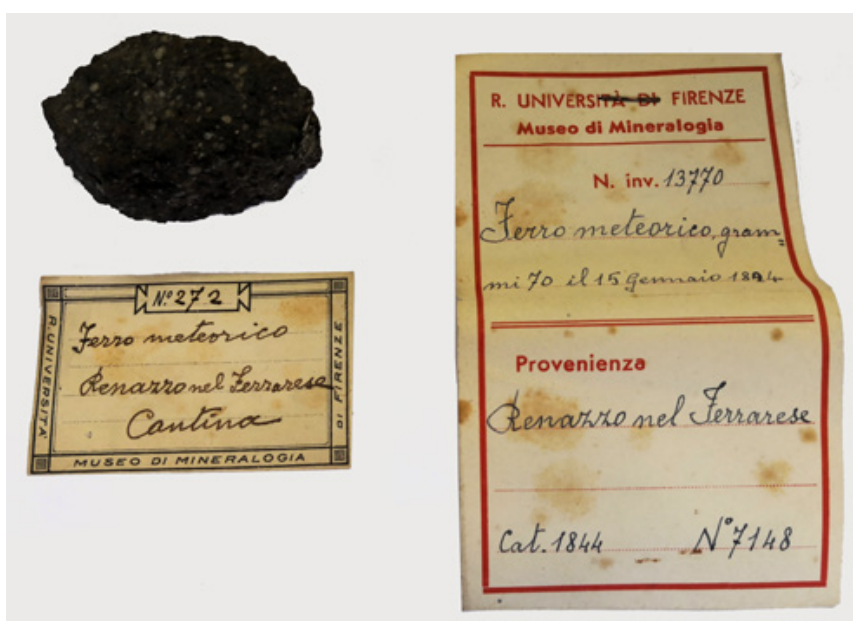

Figure 7. The largest sample (70 g) of the Renazzo meteorite preserved at the Natural History Museum of the University of Firenze, Collection of Mineralogy and Lithology, ICCD Cat. No. 1142167. 
scientific institutions. Within these funds, we can trace a letter from the Grand Duke of Tuscany Leopold II (17971870) to Girolamo Bardi (1777-1829), Director of Natural History Museum of Firenze from 1806 to 1829 [114]. On 23 March 1824, Leopold II sent to Bardi an "aerolite that fell in the village of Renazzo on the night of 15 January", which he had received from Camillo Ranzani. The Grand Duke stated that the meteorite was sent to Bardi as Director of the Natural History Museum of Firenze so that he could display it in the mineralogical collections, specifying the name of the donor on the specimen label [114] (Figure 8).

This important document (Figure 8), which represents the deed of donation of the Renazzo meteorite to the Museum, was found thanks to the cataloguing of the specimen through the BN-PL card. It reveals not only the scientific importance attributed to the meteorite Renazzo since its discovery, but also the primary role played by the meteorite exchange within naturalistic collections [10]. Furthermore, it is interesting to note how Ranzani did not send the meteorite specimen directly to Bardi, but to Leopold II, thus confirming the importance of the House of the Habsburg in the mineralogical collecting in the nineteenth century [116].

The Natural History Museum of the University of Firenze preserved a second fragment of the Renazzo meteorite, i.e. a small specimen of about $7 \mathrm{~g}$ that was acquired by the Museum in 1840 (Table 2, Figure 9).

As noted earlier, the museum catalogues provide information for the second Renazzo meteorite fragment since its acquisition by the Natural History Museum in 1840 onwards. The Catalogue of the Mineralogical Collection (18431845) described the specimen as an "aerolite, year 1824", while the inventory of the meteorite collection (1947) gave the sample a 10 lire value [120]. Even if the museum catalogues do not provide further data about the sample except for the year of acquisition, this information is crucial to trace the object's career through archival sources kept in other Florentine research institutions.

In this regard, the National Library of Firenze preserved the Targioni-Tozzetti Fonds', which includes more than 2500 documents belonging to the Targioni Tozzetti family,

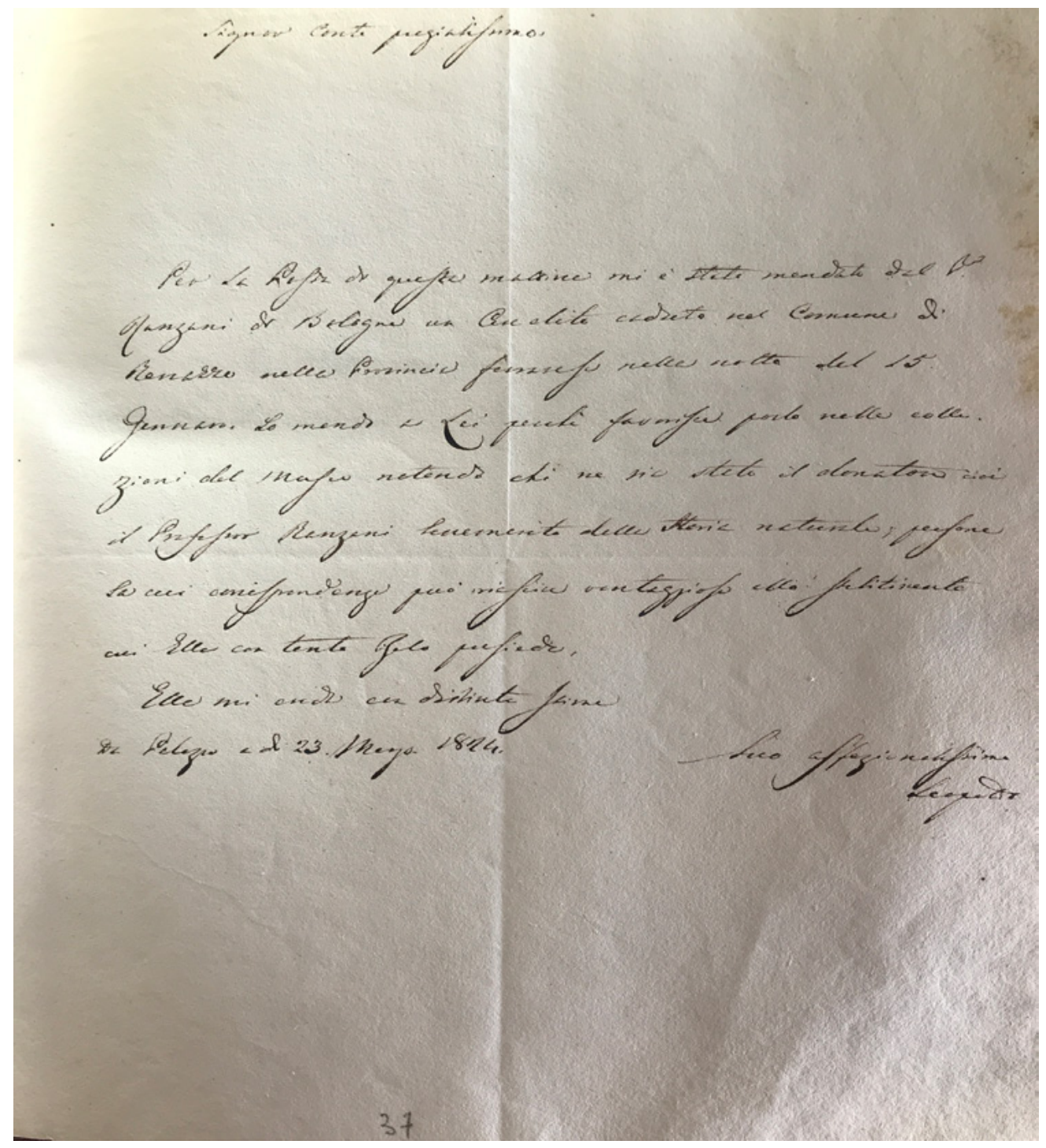

Figure 8. Letter of donation to the Florentine Imperial and Royal Museum of Physics and Natural History, by the Grand Duke Leopold II, of an aerolite fallen in the village of Renazzo and sent to him by Camillo Ranzani, 23 March 1824. Historical Archive, Galileo Museum, Firenze. 
and therefore of great interest for the history of physics and natural sciences between the eighteenth and the nineteenth centuries [123]. In this fonds is also preserved the correspondence of Ottaviano Targioni Tozzetti (1755-1826), a naturalist and an expert in mineralogy, who maintained scientific relationships with the Natural History Museum of Firenze. The analysis of Ottaviano Targioni Tozzetti's scientific correspondence showed how his studies on meteorites were well known to the scientific community of the time, to the point that he had a close exchange of letters with Ambrogio Soldani (1733-1808) about the mineralogical analyses carried out on the Siena meteorite (1794) [52, 126]. On 13 July 1824, Ottaviano Targioni Tozzetti received from Camillo Ranzani "a very small fragment of the aerolite that fell on Renazzo" in exchange for "fossil bones from Valdarno, in particular hippopotamus and rhinoceros' bones" [129] (Figure 10). On 18 December 1824, Ranzani wrote a second letter to Targioni Tozzetti to thank him for the historical notes he sent about the "aerolites fallen on Italy" that Ranzani will use as a preface to his "book on the aerolites that fell on the Cento area this year." Ranzani was, therefore, preparing to write an essay on the meteorite of Renazzo (Cento is the largest city near the place of fall). The book was never published, as Ranzani had predicted in his letter to Targioni "but when will I be able to write this book? God only knows" [130].

No further information about the Renazzo meteorite fragment sent by Ranzani to Targioni was available before the specimen was catalogued thanks to the BN-PL card. As already been said, this meteoritic sample was recorded for the first time in the museum inventory in 1840. One year before, although the negotiations had begun in 1836, the mineralogical collection belonging to the Targioni Tozzetti family was
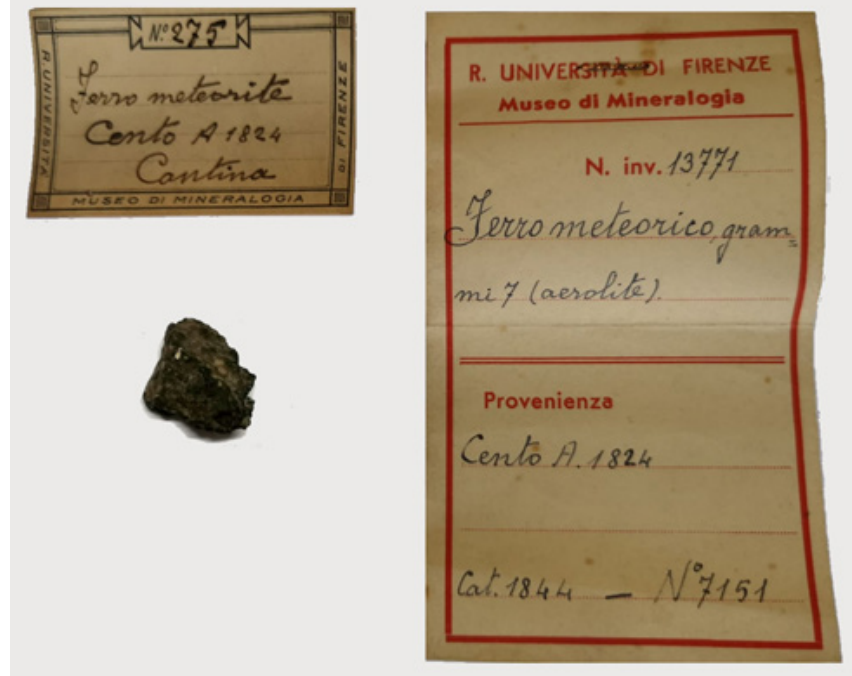

Figure 9. The smallest sample ( $7 \mathrm{~g}$ ) of the Renazzo meteorite specimen. Natural History Museum of the University of Firenze, ICCD Cat. No. 1142168 .

acquired by the Natural History Museum of Firenze for a price of 12.000 lire [131]. This mineralogical collection was initiated by the naturalist Pier Antonio Micheli (1679-1737), acquired by his pupil Giovanni Targioni Tozzetti (1712-1783) that enriched it and accompanied it with a catalogue in 12 volumes, and at last inherited from Targioni's son, Ottaviano, who added his own collection of minerals [133]. A first survey of the samples was made by the chemist Andrea Cozzi (dates uncertain) at the end of February 1839. Afterwards, the Court Secretariat of the Grand Duchy of Tuscany approved the project presented by the geologist Filippo Nesti (1780-1849) for the arrangement of the Targioni Tozzetti mineralogical collection [134]. From this standpoint, the second Renazzo meteorite specimen

Table 2. Extract of the BN-PL catalogue card for the second Renazzo meteorite specimen (ICCD Cat. No. o1142168) preserved at the Natural History Museum (Collection of Mineralogy and Lithology) of the University of Firenze.

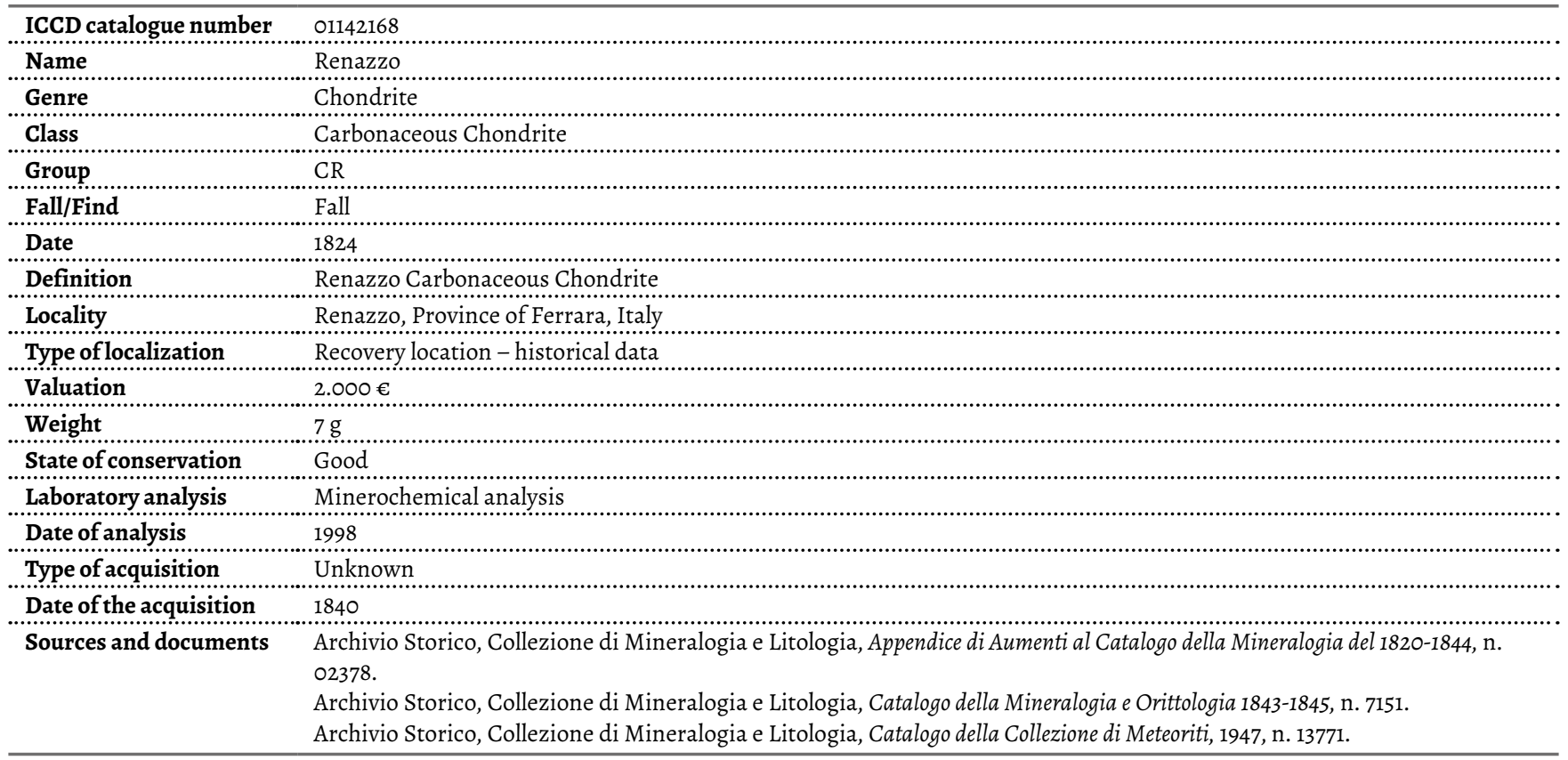




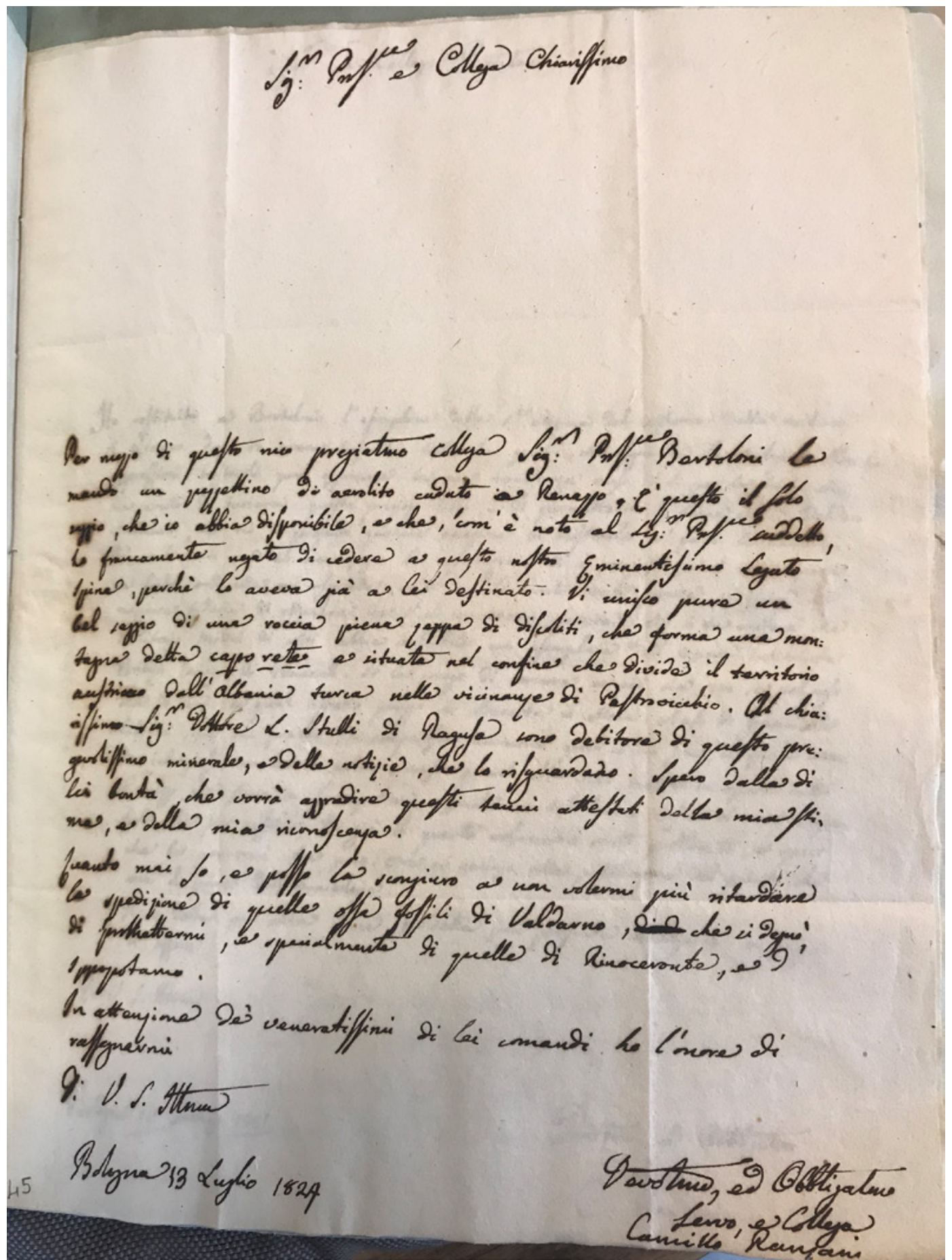

Figure 10. Letter sent to Ottaviano Targioni Tozzetti by Camillo Ranzani, which deals with the small fragment of the Renazzo meteorite, 13 July 1824. National Library of Firenze.

preserved at the Natural History Museum of Firenze can be considered as the small fragment that was sent by Camillo Ranzani to Ottaviano Targioni Tozzetti in 1824. It is important to highlight the fact that this result would not have been achieved without the cataloguing of the sample with the BN-PL card, which identified the year of the specimen's acquisition and therefore linked the archival material about the Renazzo meteorite stored in other Florentine research institutions, with the fragment preserved at the Natural History Museum of Firenze.

\section{Conclusions}

Since the early 1800 s, naturalists began to collect meteorites systematically. As might be expected, Chladni was among the first to join this activity (he possessed about 33 specimens in 1820), along with Martin Klaproth (1743-1817), Johann Blumenbach (1752-1840) and Johann Kaspar Lavater (1741-1801) (10, 135). The first catalogue that collected all the meteorite specimens belonging to a museum was published in 1847 by the Natural History Museum of London. Since 
then the catalogue has been kept up to date and its last and fifth edition was issued in 2001 [136].

Despite the fact that there is still no international standardized regulation for the cataloguing of meteorites, the BN-PL catalogue card proposed by the ICCD proves to be an efficient and scientifically valid instrument for the cataloguing of meteorite collections preserved in Italian naturalistic museums and could represent a useful guideline for an international standard. The use of the BN-PL catalogue standard within the meteorite collection of the Natural History Museum of Firenze has allowed not only the cataloguing of the Renazzo meteorite specimens, but also to trace correctly their historical and scientific background.

In conclusion, cataloguing is an essential part of managing a natural history museum on which are based important museum activities such as research, conservation, risk management, exhibition development and publications. The standardized cataloguing of meteorite collection discussed in this paper proves how meteorite specimens are part of a scientific heritage, which is important to preserve at the highest possible level of care and stewardship.

\section{Acknowledgements}

The authors would like to thank the ICCD as well as all the colleagues that have worked on the creation of a cataloguing standard for meteorite specimens preserved in natural history museums. The authors sincerely acknowledge the support of all the staff of both the Museum of Planetary Science of Prato and of the Natural History Museum of Firenze (Collection of Mineralogy and Lithology). We are also grateful to Alessandra Lenzi, archivist and librarian at the Galileo Museum in Firenze. Finally, we thank the Fondazione Cassa di Risparmio di Firenze for providing the financial support to successfully complete this article through the fund MECSO "Meteoroid Characterization through Spectroscopic Observation". The authors then thank all the staff of the Manuscript Room at the National Library in Firenze for their help during their research.

\section{REFERENCES}

1. Halliday, I. T.; Blackwell, A.; Griffin, A., 'The flux of meteorites on the Earth's surface', Meteoritics and Planetary Science

24(3) (1989) 173-178, https://doi.org/10.1111/j.1945-5100.1989. tboog59.x.

2. Zolensky, M.; Bland, P.; Brown, P.; Halliday, 'Flux of Extraterrestrial Materials', in Meteorites and the Early Solar System II, ed. S. Lauretta Dante, H.Y. McSween, University of Arizona Press, Tucson (2006) 869-888.

3. Grady, M.; Pratesi, G.; Moggi Cecchi, V., Atlas of Meteorites, Cambridge University Press, Cambridge (2014).

4. Reichenbach, K. L., 'Über die Anzhal der Meteoriten und Betrachtungen über ihire Rolle im Westgebäde', Annalen der Physik 105 (1858) 551-563.

5. Harris, J., Lexicon Technicum: or an Universal English dictionary of Arts and Sciences: explaining not only the terms of Art, but the Arts themselves, printed for J. Walthoe, Mess. Knapton, D. Midwinter, London (1736).

6. Sears, W.D., 'Edward Charles Howard and an early contribution to meteoritics', Journal of the British Astronomical
Association 86 (1976) 133-139.

7. Marvin, U.B., 'Ernst Florens Friedrich Chladni (17561827) and the origins of modern meteorite research', Meteoritics and Planetary Science 31 (1996) 15-71, https://doi. org/10.1111/j.1945-5100.1996.tbo2031.x.

8. Gounelle, M., 'The meteorite fall at L'Aigle and the Biot report: exploring the cradle of meteoritics', in The History of Meteoritics and Key Meteorite Collections: Fireballs, Falls and Finds, ed. by McCall G.J.H, Bowden A.J., Howarth R.J., The Geological Society, London (2006) 73-89.

9. Westrum, R., 'Science and social intelligence about anomalies: the case of meteorites', Social Studies of Science 8 (1978) 461-493, https://doi.org/10.1177/030631277800800403.

10. Burke, J.G., Cosmic Debris. Meteorites in history, University of California Press, Berkeley (1986).

11. Wilson, W.E. 'The history of mineral collecting, 1530-1799: with notes on twelve hundred early mineral collectors', Mineralogical Record 25(6) (1994) 1-243.

12. Lucas, A.M.; Lucas, P.J.; Darragh, T.A.; Maroske S., 'Colonial Pride and Metropolitan Expectations: The British Museum and Melbourne's Meteorites', The British Journal for the History of Science 27(1) (1994) 65-87, https://doi.org/10.1017/ So007087400031678.

13. Nair, S.P., 'Science and the politics of colonial collecting: the case of Indian meteorites', British Journal for the History of Science 39(1) (2006) 97-119, https://doi.org/10.1017/ So007087405007624.

14. Brandstätter, F., 'History of the meteorite collection of the Natural History Museum of Vienna', in The History of Meteoritics and Key Meteorite Collections: Fireballs, Falls and Finds, ed. by McCall G.J.H, Bowden A.J., Howarth R.J., The Geological Society, London (2006) 123-133.

15. Clarke, R.S.; Plotkin, H.; McCoy T., 'Meteorites and the Smithsonian Institution', in The History of Meteoritics and Key Meteorite Collections: Fireballs, Falls and Finds, ed. by McCall G.J.H, Bowden A.J., Howarth R.J., The Geological Society, London (2006) 237-265.

16. Grashake, A., 'History of the meteorite collection at the Museum für Naturkunde, Berlin', in The History of Meteoritics and Key Meteorite Collections: Fireballs, Falls and Finds, ed. by McCall G.J.H, Bowden A.J., Howarth R.J., The Geological Society, London (2006) 135-171.

17. Komorowski, C.L.V.C., 'The meteorite collection of the National Museum of Natural History in Parsi, France', in The History of Meteoritics and Key Meteorite Collections: Fireballs, Falls and Finds, ed. by McCall G.J.H, Bowden A.J., Howarth R.J., The Geological Society, London (2006) 163-204.

18. Russell, S.; Grady, M., 'A history of the meteorite collection at the Natural History Museum, London', in The History of Meteoritics and Key Meteorite Collections: Fireballs, Falls and Finds, ed. by McCall G.J.H, Bowden A.J., Howarth R.J., The Geological Society, London (2006), 153-162.

19. Hartmann, W.K., 'Chelyabinsk, Zond IV, and a possible first-century fireball of historical importance', Meteoritics and Planetary Science 50 (2015) 1-14, https://doi.org/10.1111/ maps.12428.

20. Golia, M., Meteorites: Nature and Culture, Reaktion Books, London (2015). 
21. McCoy, T.J.; Marquardt, A.E.; Wasson, J.T.; Ash, R.D.; Vicenzi, E.P., 'The Anoka, Minnesota iron meteorite as parent to Hopewell meteoritic metal beads from Havana, Illinois', Journal of Archeological Science 81 (2017) 13-22, https://doi. org/10.1016/j.jas.2017.03.003.

22. Gill, J.; Mardon A., 'Meteorites in the Culture and Beliefs of Aboriginal Peoples in North America', in 49th Lunar and Planetary Science Conference, 19-23 March 2018, The Woodlands, Texas LPI (2018) Contribution No. 2083, id.1118.

23. Bevan, A.; Bindon, P., 'Australian Aborigines and Meteorites', Records of the Wester Australian Museum 18 (1996) 93-101.

24. Hamacher, D.W.; Norris, R.P., 'Australian Aboriginal geomythology: eyewitness accounts of cosmic impacts?', Archeoastronomy 22 (2009) 60-93.

25. Hamacher, D.W., 'Meteoritics and cosmology among the Aboriginal cultures of Central Australia', Journal of Cosmology 13 (2011) 3743-3753.

26. Hamacher, D.W., Goldsmith J., 'Aboriginal oral traditions of Australian impacts craters', Journal of Astronomical History and Heritage 16(3) (2013) 295-311.

27. McCoy, T.J.; Marquardt, A.E.; Vicenzi E.P.; Ash R.D.; Wasson J.T., 'Meteoritic Metal Beads from the Havana, Illinois, Hopewell Mounds: A Source in Minnesota and Implications for Trade and Manufacture', 39th Lunar and Planetary Science Conference, 10-14 March 2008, League City, Texas (2008) LPI Contribution No. 1391., Id.1984.

28. Johnson, D.; Tyldesley J.; Lowe T.; Withers P.H.; Grady M., 'Analysis of a prehistoric Egyptian iron bead with implications for the use and perception of meteorite iron in ancient Egypt', Meteoritics and Planetary Science 48 (2013) 997-1006, https://doi. org/10.1111/maps.12120.

29. Rehren, T.; Belgya, T.; Jambon, A.; Káli, G.; Kasztovszky, Z.; Kis, Z.; Kovács, I.; Maróti, B.; Martinón-Torres, M.; Miniaci, G.; Pigott, V.C.; Radivojevic, M.; Rosta, L.; Szentmiklósi, L.; Szökefalvi-Nagy, Z., '5000 years old Egyption iron beads made from hammered meteoritic iron', Journal of Archeological Science 40 (2013) 4785-4792, https://doi.org/10.1016/j.jas.2013.06.002.

30. Comelli, D.; D’Orazio, M.; Folco, L.; El-Halwagy, M.; Frizzi, T.; Alberti, R.; Capogrosso, V.; Einaggar, A.; Hassan, H.; Nevin, A.; Porcelli, F.; Rashed, M.G.; Valentini, G., 'The meteoritic origin of Tutankhamun's iron dagger', Meteoritics and Planetary Science 51(7) (2016) 1301-1309, https://doi.org/10.1111/ maps.12664.

31. Jambon, J., 'Bronze Age Iron: Meteoritic or not? A Chemical Strategy', Journal of Archeological Science 88 (2017) 47-53, https:// doi.org/10.1016/j.jas.2017.09.008.

32. Chen, K.; Wang, Y.; Liu, Y.; Mei, J.; Jiang, T., 'Meteoritic origin and manufacturing process of iron blades in two Bronze Age bimetallic objects from China', Journal of Cultural Heritage 30 (2018) 45-50, https://doi.org/10.1016/j.culher.2017.10.004.

33. Dorfman, E. (ed.), Intangible Natural Heritage: New Perspectives on Natural Objects, Routledge, New York (2012).

34. Ahmed, Y., 'The scope and definitions of heritage: from tangible to intangible', International Journal of Heritage Studies 12(3) (2006) 292-300, https://doi. org/10.1080/13527250600604639.

35. Wilson, R.J, Natural History. Heritage, Place and Politics, Routledge, New York (2018).
36. Elmann, A.J.; Keli, K., 'Classification of four ordinary chondrites from the Monnig Meteorite Collection', Meteoritics and Planetary Science 27(4) (1992) 470-472, https://doi. org/10.1111/j.1945-5100.1992.tboo232.x.

37. Gattacceca, J.; Bourot-Denise, M.; Brandstaetter, F.; Folco, L.; Rochette, P., 'The Asco meteorite (1805): New petrographic description, chemical data, and classification', Meteoritics and Planetary Science 42(8) (2007) A173-A176, https://doi. org/10.1111/j.1945-5100.2007.tbo0602.x.

38. Moggi Cecchi, V., 'The application of the Raman spectroscopy to the study of meteorites and minerals belonging to the collections of the Museo di Scienze Planetarie della Provincia di Prato', Museologia Scientifica 11 (2014) 157-160.

39. Wasson, J.T., 'Campo del Cielo: a Campo by any other name', Meteoritics and Planetary Science 54(2) (2018) 280-289, https:// doi.org/10.1111/maps.13205.

40. Llorca, J.; Campeny, M.; Ibáñez, N.; Allepuz, D.; Camarasa, J.M.; Aurell-Garrido J., 'The meteorite of Barcelona (1704): History, discovery and classification', Meteoritics and Planetary Science [Online Version of Record before inclusion in an issue] (2020), https://doi.org/10.1111/maps.13455.

41. Moggi Cecchi, V.; Carpino, S.; Pratesi, G.; Caporali, S.; Manetti, F., 'Tale of a rediscovered meteorite: the case of the meteorite Slaghek's Iron', Museologia Scientifica 14 (2015) 166-168.

42. Moggi Cecchi, V.; Rossi, M.; Ghiara, M.R.; Pratesi G.; Franza $A$, 'An unrevealed treasure: a new Italian meteorite from the Royal Mineralogical Museum of Naples', Geology Today 35(6) (2019) 212-216, https://doi.org/10.1111/gto.12293.

43. Pratesi, G.; Caporali, S.; Greenwoord, R.C.; Moggi Cecchi, V.; Franchi, I.A., 'A detailed mineralogica, petrographic, and geochemical study of the highly reduced chondrite, Acfer 370', Meteoritics \& Planetary Science 54 (2019) 2996-3017, https://doi. org/10.1111/maps.13409.

44. De Chadarevian, S., 'Things and the archives of recent sciences', Studies in History and Philosophy of Science 44 (2013) 634-638, https://doi.org/10.1016/j.shpsa.2013.07.005.

45. Veggiani, A., Sulla caduta di una meteorite nel 1496 a Valdinoce nel territorio cesenate, Lega, Faenza (1964).

46. Tinazzi, M., 'A meteorite fallen in ' 600 near Vago (Verona)', Memorie della Società astronomica italiana 55(2) (1994) 547-566.

47. Barbieri, F.; Zuccoli, M., 'Note d'archivio: il vescovo Fogliani e la meteorite di Albareto', Atti della Società dei naturalisti e dei matematici di Modena 128 (1997) 173-179.

48. Guidone, N. La meteorite Fermo. Grafiche Bonassi, Fermo (1997).

49. Cevolani, G., Fermo, la meteorite: l'ultima pietra celeste del secondo millennio, Zefiro, Fermo (2005).

50. Marvin, U.B.; Cosmo, L., 'Domenico Troili (1766): “The true cause of the fall of a stone in Albereto is a subterranean explosion that hurled the stone skyward"', Meteoritics and Planetary Science 37(12) (2010) 1857-1864, https://doi. org/10.1111/j.1945-5100.2002.tbo1169.x.

51. Olson, R.J.M.; Pasachoff, J.M., 'Comets, meteors, and eclipses: Art and science in early Renaissance Italy', Meteoritics and Planetary Science 37(11) (2010) 1563-1578, https://doi. org/10.1111/j.1945-5100.2002.tboo811.x.

52. Levi Donati, G., 'La meteorite di Siena: una pagina importante nella storia della scienza', Atti dell'Accademia delle Scienze di 
Siena detta de' Fisiocritici 15 (1994) 19-25.

53. Marvin, U.B., 'The shower of stones at Siena, 1794: history's most consequential meteorite fall', in INHIGEO. Volcanoes and History, ed. by N. Morello N., Brigati, Genova (1998) 303-321.

54. Folco, L.; D'Orazio, M.; Perchiazzi, N., 'Authenticating the recovery location of meteorites: The case of Castenaso', Meteoritics and Planetary Science 42(3) (2007)321-330, https:// doi.org/10.1111/j.1945-5100.2007.tb00236.x.

55. Schmitt, D.G., 'The law of ownership and control of meteorites', Meteoritics and Planetary Science 37 (2002) B5-B11, https://doi.org/10.1111/j.1945-5100.2002.tboo897.x.

56. Gounelle, M.; Gounelle, M., 'Meteorites: International law and regulations', Meteoritics and Planetary Science 54(12) (2019) 28872901, https://doi.org/10.1111/maps.13396.

57. Levi Donati, G., 'The meteorite collection of Giorgio Abetti Astronomical Observatory and Museum, San Giovanni in Persiceto, Bologna, Italy: An update of the catalog', Meteoritics and Planetary Science 31 (1996) A181-A186, https://doi. org/10.1111/j.1945-5100.1996.tbo2102.x.

58. Cipriani, C.; Corazza, M., 'Le meteoriti del Museo di Mineralogia di Firenze: nota I', Museologia Scientifica 14 (1998) 229-246.

59. Cipriani, C.; Corazza, M.; Olmi, F.; Pratesi, G., 'Le meteoriti del Museo di Mineralogia di Firenze: nota II, le condriti ordinarie', Museologia Scientifica 15 (1999) 183-194.

60. Folco, L.; Rastrelli, N., 'The meteorite collection of the Museo Nazionale dell'Antartide in Siena', Meteoritics and Planetary Science 35 (2000) A189-A198, https://doi. org/10.1111/j.1945-5100.2000.tbo1795.x.

61. Folco, L.; Pieri, F.; Pezzotta, F., 'The meteorite collection of the Civico Planetario and the Museo Civico di Storia Naturale in Milan, Italy', Meteoritics and Planetary Science 37 (2002) B95-B103, https://doi.org/10.1111/j.1945-5100.2002.tbo0908.x.

62. Pratesi, G., 'Per aspera ad astra: la collezione di meteoriti', in $\mathrm{Il}$ Museo di Storia Naturale dell'Università degli Studi di Firenze, ed. by Pratesi G., Firenze University Press, Firenze (2012) 127-141.

63. Alberti, S., 'Objects and the Museum', Isis 96 (2005) 559-571, http://doi.org/10.1086/498593.

64. Byrne, S.; Clarke, A.; Harrison, R.; Torrence, R., 'Networks, agents and objects: frameworks for unpacking museum collections', in Unpacking the Collection: Networks of Material and Social Agency in the Museum, ed. by Byrne S., Harrison R., Torrence R., Springer, New York, (2011) 3-26.

65. Godsden, C., Larson, F.; Petch, A., Knowing things: Exploring the Collections at the Pitt Rivers Museum 1884-1945, Oxford University Press, Oxford (2007).

66. Bennett, T., 'Making and Mobilising Worlds: Assembling and Governing the Other', in Material Powers: Cultural Studies, History and the Material Turn, ed. by Bennett T. and Joyce P., Routledge, London (2010) 188-208.

67. Macdonald, S. (ed.), The politics of display: museums, science, culture, Routledge, London/New York (2010).

68. Calosso, B.; Di Lorenzo, A.; Lattanzi, M., 'SIGEC: General Information System for the Cataloguing of the National Cultural Heritage', Museologia Scientifica 2 (2008) 21-24.

69. Hunter, M., Preserving the past: The rise of heritage in modern Britain, Alan Sutton, Stroud (1996).

70. Lowenthal, D., The heritage crusade and spoils of history,
Cambridge University Press, Cambridge (1998).

71. Boundia, S.; Soubiran, S., 'Scientists and their cultural heritage: Knowledge, politics and ambivalent relationships', Studies in History and Philosophy of Science 44 (2013) 643-651, https://doi.org/10.1016/j.shpsa.2013.07.002.

72. Alivizatou, M., Intangible heritage and the museum: new perspectives on cultural preservation, Left Coast Press, Walnut Creek (2012).

73. Talas, S.; Lourenço M.C., Arranging and rearranging: planning university heritage for the future, Padova University Press, Padova (2012).

74. Mouliou, M.; Soubiran, S.; Talas, S.; Wittje, R. (eds.), Turning inside out European University Heritage: Collections, Audiences, Stakeholders, National and Kapodistrian University of Athens Press, Athens (2018).

75. Fairclough, G.; Dragićević-Šešić, M.; Rogač-Mijatović, L.; Auclair, E.; Soini, K., 'The Faro Convention, a new paradigm for socially - and culturally - sustainable heritage action?', Kymypa/Culture 8 (2015) 9-19.

76. Schofield, J., 'Forget about 'Heritage': Place, Ethics and the Faro Convention', in The Ethics of Cultural Heritage, ed. by T. Ireland, J. Schoofield, Springer, New York (2015), 197-209, https://doi.org/10.1007/978-1-4939-1649-8_12.

77. Lourenço, M.C., Wilson, L., 'Scientific heritage: Reflections on its nature and new approaches to preservation, study and access', Studies in History and Philosophy of Science 44 (2013) 744753, https://doi.org/10.1016/j.shpsa.2013.07.011.

78. Ferrari, G, Proceedings of the workshop: Historical seismic instruments and documents: a heritage of great scientific and cultural value, May 16th to 18th, 1994, Walferdange (Grand-Duchy of Luxembourg) organized by the European seismological commission (ESC), WG History of seismometry and the European centre for geodynamics and seismology (EUR-OPA Major Hazards), Centre européen de géodynamique et de séismologie, Luxembourg (1997).

79. Amparo, S., 'Strumentaria learned institutions: sources for unknown scientific instruments', Nuncius 14 (1999) 491-504, https://doi.org/10.1163/182539199X00058.

80. Fara, P., 'Isaac Newton lived here: sites of memory and scientific heritage', British Journal for the History of Science 33 (2000) 407-426, https://doi.org/10.1017/S0007087400004192.

81. Beretta, M., 'Reconstructing science: contributions to enhancement of European scientific heritage', Nuncius 16 (2000) 799-816, https://doi.org/10.1163/182539101X00721.

82. Jardine, N., 'Reflections on the preservation of recent scientific heritage in dispersed university collections', Studies in History and Philosophy of Science 44 (2013) 735-743, https://doi. org/10.1016/j.shpsa.2013.07.009.

83. Epifania, P.; Sungging Mumpuni, E., 'Bosscha observatory: challenges as a scientific heritage of astronomy in Indonesia', in The role of astronomy in society and culture, ed. by D. VallsGabaud and A. Boksenberg, Cambridge University Press, Cambridge (2011) 235-240.

84. Ludwig, D.; Weber, C., 'A rediscovery of scientific collections as material heritage? The case of university collections in Germany', Studies in History and Philosophy of Science 44 (2013) 652-659, https://doi.org/10.1016/j.shpsa.2013.07.012.

85. Tucci, R., Le voci, le opere e le cose. La catalogazione dei beni culturali demoetnoantropologici, ICCD, Roma (2018). 
86. Vasco Rocca, S., Beni culturali e catalogazione. Principi teoricie percorsi di analisi, Gangemi Editori, Roma (2002).

87. Corti, L., I beni culturali e la loro catalogazione, Bruno Mondadori, Milano (2003).

88. Corradini, E., 'Cataloguing and new computer technologies to make naturalistic heritage accessible', Museologia scientifica 9 (2013) 33-39.

89. Moro, L., 'Conoscenza e valorizzazione dei beni scientifici e naturalistici', in I valori del Museo. Politiche di indirizzo e strategie digestione, ed. by Pratesi G., Vannozzi, F., FrancoAngeli, Milano (2014) 13-17.

90. Casto, L.; Celi, M.; Ferrante, F.; Francescangeli, R.; Pesce, G.B.; Pezzotta, F.; Pizzo, M.; Pratesi, G.; Scandurra, P.; Zorzin, R., Scheda BNPL. Beni Naturalistici-Planetologia, ICCD, Roma (2007).

91. Pratesi, G.; Bartolozzi, L.; Cioppi, E.; Di Fazio, L.; Nepi, C.; Poggi, L.; Zavattaro, M., 'Individuazione dei criteri per la stima del valore dei beni naturalistici e demoetnoantropologici', in I valori del Museo. Politiche di indirizzo e strategie di gestione, ed. by Pratesi G., Vannozzi, F., FrancoAngeli, Milano (2014) 81-97.

92. Weisberg, M.K.; McCoy, T.J.; Krot, A.N.; 'Systematics and Evaluation of Meteorite Classification', in Meteorites and the Early Solar System II, ed. by Lauretta Dante S., McSween, H.Y., University of Arizona Press, Tucson, (2006) 19-52.

93. Pratesi., G.; Morelli, M.; Rossi, A.P.; Gori, G.G., 'Chemical compositions of impact melt breccias and target rocks from the Tenoumer impact crater, Mauritania', Meteoritics and Planetary Science 40 (2005) 1653-1672, https://doi. org/10.1111/j.1945-5100.2005.tboo137.x.

94. Throsby, D.; Withers, A., 'What price culture', Journal of Cultural Economics 9 (1985) 1-34, https://doi.org/10.1007/ BFoo187742.

95. Pearce, D.W.; Mourato, S., The Economics of Cultural Heritage. World Bank Report, CSERGE, London (1988).

96. Throsby, D., 'Cultural Capital', Journal of Cultural Economics 23 (1999) 3-12, https://doi.org/10.1023/A:1007543313370.

97. Fromm, O., 'Ecological structure and functions of biodiversity as elements of its total economic value', Environmental and Resource Economics 16 (2000) 303-328, https://doi. org/10.1023/A:1008359022814.

98. Dalton, R., 'Natural history collections in crisis as funding is slashed', Nature 423 (2003) 575, https://doi.org/10.1038/423575a.

99. Froelich, A., 'Smithsonian science: first class on a coach budget', Bioscience 53 (2003) 328, https://doi.org/10.1641/00063568(2003)053[0328:SSFCOA]2.0.CO;2.

100. Suarez, A.V.; Tstsui, N.D., 'The value of museum collections for research and society', BioScience 54(1) (2004) 66-74, https:// doi.org/10.1641/0006-3568(2004)054[0066:TVOMCF]2.0.CO;2. 101. Bradley, R.D.; Bradley, L.C.; Garner, H.J.; Baker, R.J., 'Assessing the value of natural history collections and addressing issues regarding long-term growth and care', Bioscience 64 (12) (2014) 1150-1158, https://doi.org/10.1093/ biosci/biu166.

102. Buchner, L.O., Die Meteoriten in Sammlungen, W. Engelmann, Leipzig (1863), https://doi.org/10.1002/andp.18641980611.

103. Wülfing, E.A., Die Meteoriten in Sammlungen und Ihre Literatur, nebst einem Versucht, den Tauschwert der Meteoriten zu
Bestimmen, Tübingen (1897).

104. Moggi Cecchi, V.; Pratesi, G.; Carpino, S.; Caporali, S., 'The meteorite classification on behalf of a third party as an efficient tool for the economic valorisation and the scientific promotion of the heritage of the naturalistic collections', Museologia Scientifica 17 (2017) 144-147.

105. Cokinos, C., The Fallen Sky. An Intimate History of Shooting Stars, Penguin, New York (2009).

106. Cevolani, G., Renazzo: un meteorite racconta la nostra storia, Sicca Arti Grafiche, Cento (2001).

107. Corsi, P., 'Ranzani, Camillo', in Dizionario Biografico degli Italiani, Istituto della Enciclopedia Italiana, Roma (2016) vol. 28 470-472.

108. Newcomb, S., 'With a little help from friends: Pierre-LouisAntoine Cordier (1777-1861): 50 years of experimental work on basalt', Earth Science History 34(2) (2017) 204-219, https://doi. org/10.17704/1944-6187-34.2.204.

109. Cordier, P.L.A., Description des roches composant l'écorce terrestre et des terrains cristallins constituant le sol primitif, par Charles D’Orbigny, Paris (1868).

110. Weisberg, K.M.; Prinz, M.; Clayton, R.N. ; Mayeda, T.K., 'The CR (Renazzo-type) carbonaceous chondrite group and its implications', Geochimica et Cosmochimica Acta 57 (7) (1993) 1567-1586, https://doi.org/10.1016/0016-7037(93)90013-M.

111. Historical Archive, Natural History Museum of the University of Firenze, Collection of Mineralogy and Lithology, Appendice di Aumenti al Catalogo della Mineralogia del 1824, n. 00525.

112. Historical Archive, Natural History Museum of the University of Firenze, Collection of Mineralogy and Lithology, Catalogo della Mineralogia e Orittologia, 1843-1845, n. 7148.

113. Historical Archive, Natural History Museum of the University of Firenze, Collection of Mineralogy and Lithology, Catalogo della Collezione di Meteoriti, 1947, n. 13770.

114. Historical Archive, Galileo Museum, ARMU Affari 038, Carteggio della Direzione, gennaio-dicembre 1824, c. 37.

115. Vadalà, M.E., Girolamo dei Bardi (177-1829): collezionismo librario e educazione popolare a Firenze agli inizi del XIX secolo, Accademia Bardi, Vernio (2017).

116. Vogel, K., 'Social, Cultural and Political Spaces in the 18th and Early 19th Century' Historical Social Research 40 (1) (2015) 301320, https://doi.org/10.12759/hsr.40.2015.1.301-320.

117. Franza, A.; Fabozzi, R.; Vezzosi, L.; Fantoni, L.; Pratesi, G., 'The Catalog of the Mineralogical Collection of the Emperor Leopold II (1747-1792): Collecting and Learning in EighteenthCentury Europe', Earth Science History 38 (2) (2019) 173-203, https://doi.org/10.17704/1944-6178-38.2.173.

118. Klemum, M., 'Geology takes form: Museums in the Habsburg Empire, 1815-1848', in Museums at the Forefront of the History and Philosophy of Geology: History Made, History in the Making, ed. by Rosemberg, G.D., Clary, R.M., Geological Society of America Special Paper, The Geological Society of America (2018) 163-175.

119. Klemum, M., 'Spaces and places: an historical overview of the development of geology in Austria (Habsburg Monarchy) in the eighteenth and nineteenth centuries', in History of geoscience: Celebrating 50 Years of INHIGEO, ed. Mayer M., Clary R.M., Azuala L. F., Mota T. S., Geological Society, London (2017) 263-270.

120. Historical Archive, Natural History Museum of the 
University of Firenze, Collection of Mineralogy and Lithology, Appendice di Aumenti al Catalogo della Mineralogia del 1824-1844, n 02378.

121. Historical Archive, Natural History Museum of the University of Firenze, Collection of Mineralogy and Lithology, Catalogo della Mineralogia e Orittologia, 1843-1845, n. 7151.

122. Historical Archive, Natural History Museum of the University of Firenze, Collection of Mineralogy and Lithology, Catalogo della Collezione di Meteoriti, 1947, n. 13771.

123. Fontana Semerano S.; Schiavotti Morena, M., Le carte di Giovanni Targioni Tozzetti conservate nella Biblioteca nazionale centrale di Firenze, Giunta Regionale Toscana, Firenze (1989).

124. Accademia dei Georgofili di Firenze, Museo di Storia Naturale dell'Università degli Studi di Firenze, I Targioni Tozzettifra '700 e ' 900 , Firenze University Press, Firenze (2006).

125. Cipriani, C.; Scarpellini, A., Un contributo alla mineralogia settecentesca: la collezione di Giovanni Targioni Tozzetti, L.S. Olschki, Firenze (2007).

126. Vergari, D., 'La corrispondenza di Ottaviano Targioni Tozzetti', Nuncius 17 (1) (2002) 91-155, https://doi. org/10.1163/182539102X00630.

127. Rodolico, F., 'Ambrogio Soldani e Ottaviano Targioni Tozzetti: carteggio sulla pioggetta di sassi del 1794', Physis $\mathbf{1 2}$ (2) (1970) 197-210.

128. Cipriani, C.; Nepi, C.; Poggi, L., Opuscoli e schede mineralogiche: manoscritti e lettere di Ottaviano Targioni Tozzetti: conoscenze naturalistiche a Firenze tra Sette e Ottocento, L.S. Olschki, Firenze (2000).

129. National Library of Florence, Targioni Tozzetti Fonds, Lettere Autografe di diversi uomini celebri e persone distinte a Ottaviano Targioni Tozzetti, Targ. 75, vol. III, c. 45.
130. National Library of Florence, Targioni Tozzetti Fonds, Lettere Autografe di diversi uomini celebri e persone distinte a Ottaviano Targioni Tozzetti, Targ. 75, vol. III, c. 49.

131. Historical Archive, Galileo Museum, ARMU, Registro del carteggio in uscita della Direzione, 18 gennaio-30 dicembre 1836, p. 47.

132. Historical Archive, Galileo Museum, ARMU Spese 058, Spese e contabilità, novembre 1838-gennaio 1840, aff. 1 bis.

133. Cipriani, C.; Fantoni, L.; Poggi, L.; Scarpellini, A., Le collezioni mineralogiche del Museo di Storia Naturale dell'Università degli Studi di Firenze dalle origini a oggi, L.S. Olschki, Firenze (2011).

134. Historical Archive, Galileo Museum, ARMU Affari 051, Carteggio della Direzione, febbraio 1837 - dicembre 1839, c. 27.

135. Schreibers, K., Beyträge zur Geschichte und Kenntniß meteorischer Stein- und Metall-Massen, und der Erscheinungen, welche deren Niederfallen zu begleiten pflegen, Heubner, Wien (1820).

136. Grady, M., Catalogue of Meteorites, Cambridge University Press, Cambridge (2001).

RECEIVED: 2020.4 .21

REVISED: 2020.8 .8

ACCEPTED: 2020.8 .13

ONLINE: 2020.11.4

\section{(c) (1) (3)}

This work is licensed under the Creative Commons Attribution-NonCommercial-NoDerivatives 4.0 International License. To view a copy of this license, visit

http://creativecommons.org/licenses/by-nc-nd/4.o/deed.en. 